\title{
Achillea millefolium L. hydroethanolic extract inhibits growth of human tumor cell lines by interfering with cell cycle and inducing apoptosis
}

\author{
Joana M. Pereira ${ }^{\mathrm{a}, \mathrm{b}, \mathrm{c}}$, Vanessa Peixoto ${ }^{\mathrm{c}}$, Alexandra Teixeiraa ${ }^{\mathrm{a}, \mathrm{b}}$, Diana Sousa ${ }^{\mathrm{a}, \mathrm{b}}$, Lillian Barros $^{\mathrm{d}}$, \\ Isabel C.F.R. Ferreira ${ }^{\mathrm{d}, *}$, M. Helena Vasconcelos ${ }^{\mathrm{a}, \mathrm{b}, \mathrm{c}, * *}$ \\ a Instituto de Investigação e Inovação em Saúde (i3S), Universidade do Porto, Porto, Portugal \\ ${ }^{\mathrm{b}}$ Cancer Drug Resistance Group, Institute of Molecular Pathology and Immunology of the University of Porto (IPATIMUP), Porto, Portugal \\ ${ }^{\mathrm{c}}$ Department of Biological Sciences, Faculty of Pharmacy, University of Porto, Porto, Portugal \\ d Centro de Investigação de Montanha (CIMO), Instituto Politécnico de Bragança, Bragança, Portugal
}

\section{A R T I C L E I N F O}

\section{Keywords:}

A. millefollium

Hydroethanolic extract

Phenolic compounds

Tumor cell growth

Cell cycle

Apoptosis

\begin{abstract}
A B S T R A C T
The cell growth inhibitory activity of the hydroethanolic extract of Achillea millefolium was studied in human tumor cell lines (NCI-H460 and HCT-15) and its mechanism of action was investigated. The GI so $_{\text {concentration }}$ was determined with the sulforhodamine B assay and cell cycle and apoptosis were analyzed by flow cytometry following incubation with PI or Annexin V FITC/PI, respectively. The expression levels of proteins involved in cell cycle and apoptosis were analyzed by Western blot. The extracts were characterized regarding their phenolic composition by LC-DAD-ESI/MS. 3,5-O-Dicaffeoylquinic acid, followed by 5 - $O$-caffeoylquinic acid, were the main phenolic acids, while, luteolin- $O$-acetylhexoside and apigenin- $O$-acetylhexoside were the main flavonoids. This extract decreased the growth of the tested cell lines, being more potent in HCT-15 and then in NCIH460 cells. Two different concentrations of the extract (75 and $100 \mu \mathrm{g} / \mathrm{mL}$ ) caused alterations in cell cycle profile and increased apoptosis levels in HCT-15 and NCI-H460 cells. Moreover, the extract caused an increase in p53 and p21 expression in NCI-H460 cells (which have wt p53), and reduced XIAP levels in HCT-15 cells (with mutant p53). This work enhances the importance of A. millefolium as source of bioactive phenolic compounds, particularly of XIAP inhibitors.
\end{abstract}

\section{Introduction}

Cancer is one of the most lethal diseases in the world, being the leading cause of death in economically developed countries and the second one in developing countries. It is crucial to find new efficient therapies to treat this disease (Holohan et al., 2013). Plants were traditionally used in the past to treat cancer and nowadays, especially in developing countries, a large percentage of the population is still using plants instead of the pharmaceutical products available (Uniyal et al., 2006). Therefore, the presence of bioactive compounds in plants and other natural products has been extensively investigated by many scientists, in order to apply this knowledge to the treatment of cancer.

Achillea millefolium, also known as yarrow, belongs to the Asteraceae family and is a traditional plant that can be found in several countries of Europe, Asia, North Africa and North America (Potrich et al., 2010; Vitalini et al., 2011). This plant has been used during centuries to treat several conditions, such as gastrointestinal and hepatobiliary disorders, inflammation and diabetes (Akram, 2013; Benedek and Kopp, 2007). Its sedative properties were also described, since recent studies have shown that a hydroalcoholic extract of $A$. millefolium has anxiolytic effects in vivo (Baretta et al., 2012). In addition, this plant can be used in a distillate solution as a disinfectant due to its antibacterial effect (Miranzadeh et al., 2015). Interestingly, some studies showed the antitumor potential of some extracts of A. millefolium in human tumor cell lines (Csupor-Loffler et al., 2009; Dias et al., 2013). In the case of aqueous and methanolic extracts, the bioactivity was related with phenolic compounds, mainly phenolic acid derivatives (caffeoylquinic acid derivatives) and flavones (Dias et al., 2013).

The aim of this work was to investigate the tumor cell growth inhibitory effect of the hydroethanolic extract of $A$. millefolium in different human tumor cell lines: NCI-H460 (non-small cell lung cancer), and HCT-15 (human colorectal adenocarcinoma). Moreover, the effects of the hydroethanolic A. millefolium extract on the cell cycle profile and apoptosis were also studied in these cell lines.

\footnotetext{
Abbreviations: FBS, Fetal Bovine Serum; PBS, Phosphate Buffer Solution; RT, Room Temperature; SRB, Sulforhodamine B

* Corresponding author. Centro de Investigação de Montanha (CIMO), Instituto Politécnico de Bragança, Bragança, Portugal.

** Corresponding author. Instituto de Investigação e Inovação em Saúde (i3S), Universidade do Porto, Porto, Portugal.

E-mail addresses: iferreira@ipb.pt (I.C.F.R. Ferreira), hvasconcelos@ipatimup.pt (M.H. Vasconcelos).
} 
Table 1

Phenolic compounds profile of the Achillea millefolium L. hydroethanolic extract.

\begin{tabular}{|c|c|c|c|c|c|c|}
\hline Peak & Rt (min) & $\begin{array}{l}\lambda_{\max } \\
(\mathrm{nm})\end{array}$ & $\begin{array}{l}\text { Pseudomolecular ion } \\
{[\mathrm{M}-\mathrm{H}]^{-}(\mathrm{m} / \mathrm{z})}\end{array}$ & $\begin{array}{l}\mathrm{MS}^{2} \\
(m / z)\end{array}$ & Identification & $\begin{array}{l}\text { Quantification } \\
\text { (mg/g extract) }\end{array}$ \\
\hline 1 & 5.2 & 324 & 353 & 191(100),179(67),173(5),135(43) & 3-O-Caffeoylquinic acid & $0.21 \pm 0.01$ \\
\hline 2 & 6.5 & 324 & 341 & $179(100)$ & Caffeic acid hexoside & $0.060 \pm 0.002$ \\
\hline 3 & 7.3 & 326 & 353 & $191(54), 179(86), 173(100), 135(33)$ & 4-O-Caffeoylquinic acid & $0.255 \pm 0.003$ \\
\hline 4 & 8.1 & 328 & 353 & 191(100),179(10),173(8),135(5) & 5-O-Caffeoylquinic acid & $5.12 \pm 0.04$ \\
\hline 5 & 11.4 & 332 & 593 & $473(21), 383(10), 353(25)$ & Apigenin- $C$-hexoside- $C$-hexoside & $0.102 \pm 0.003$ \\
\hline 6 & 15.1 & 334 & 563 & $473(10), 443(13), 383(22), 353(20)$ & Apigenin- $C$-hexoside-C-pentoside & $0.163 \pm 0.003$ \\
\hline 7 & 15.4 & 341 & 563 & $473(12), 443(21), 383(12), 353(24)$ & Apigenin- $C$-glucose- $C$-pentoside & $0.101 \pm 0.004$ \\
\hline 8 & 16.4 & 348 & 447 & $357(80), 327(85), 297(32), 285(12)$ & Luteolin-6-C-glucoside & $0.072 \pm 0.001$ \\
\hline 9 & 17.4 & 354 & 595 & $301(100)$ & Quercetin-O-pentosyl-hexoside & $0.032 \pm 0.001$ \\
\hline 10 & 17.7 & 354 & 463 & $301(100)$ & Quercetin-O-hexoside & $0.58 \pm 0.03$ \\
\hline 11 & 18.2 & 344 & 695 & $651(100), 609(3), 447(17), 301(15)$ & Quercetin-O-malonylhexosyl-rhamnoside & $0.093 \pm 0.004$ \\
\hline 12 & 19.5 & 348 & 579 & $417(8), 285(42)$ & Kaempferol-O-pentosyl-hexoside & $0.069 \pm 0.002$ \\
\hline 13 & 19.6 & 352 & 609 & $301(100)$ & Quercetin-3-O-rutinoside & $0.20 \pm 0.01$ \\
\hline 14 & 20.5 & 342 & 593 & $269(100)$ & Apigenin-O-dihexoside & $0.12 \pm 0.01$ \\
\hline 15 & 20.6 & 356 & 477 & $315(100)$ & Isorhamnetin- $O$-hexoside & $0.086 \pm 0.002$ \\
\hline 16 & 21.0 & 328 & 515 & $353(70), 335(32), 191(40), 179(71), 173(91), 161(16), 135(22)$ & 3,4-O-Dicaffeoylquinic acid & $1.18 \pm 0.04$ \\
\hline 17 & 21.4 & 350 & 505 & $301(100)$ & Quercetin-O-acetylhexoside & $0.35 \pm 0.01$ \\
\hline 18 & 22.4 & 352 & 505 & $301(100)$ & Quercetin-O-acetylhexoside & $0.18 \pm 0.01$ \\
\hline 19 & 22.6 & 328 & 515 & $353(96), 335(4), 191(100), 179(71), 173(8), 161(12), 135(20)$ & cis 3,5-O-Dicaffeoylquinic acid & $7.55 \pm 0.09$ \\
\hline 20 & 22.9 & 328 & 515 & $353(90), 335(10), 191(100), 179(65), 173(7), 161(11), 135(12)$ & trans 3,5-O-Dicaffeoylquinic acid & $5.51 \pm 0.01$ \\
\hline 21 & 23.5 & 340 & 563 & $269(100)$ & Apigenin-O-pentosyl-hexoside & $0.24 \pm 0.01$ \\
\hline 22 & 25.4 & 328 & 515 & 353(15),335(3),191(44),179(59),173(81),161(14),135(15) & 4,5-O-Dicaffeoylquinic acid & $2.20 \pm 0.02$ \\
\hline 23 & 25.5 & 330 & 431 & $269(100)$ & Apigenin-7-O-glucoside & $0.294 \pm 0.002$ \\
\hline 24 & 26.2 & 348 & 489 & $285(100)$ & Luteolin-O-acetylhexoside & $1.40 \pm 0.05$ \\
\hline 25 & 28.3 & 350 & 519 & $315(100)$ & Isorhamnetin-O-acetylhexoside & $0.039 \pm 0.001$ \\
\hline 26 & 29.2 & 338 & 473 & $269(100)$ & Apigenin- $O$-acetylhexoside & $0.070 \pm 0.002$ \\
\hline 27 & 30.3 & 338 & 473 & $269(100)$ & Apigenin-O-acetylhexoside & $1.14 \pm 0.03$ \\
\hline \multirow[t]{2}{*}{28} & 31.2 & 340 & 473 & $269(100)$ & Apigenin-O-acetylhexoside & $0.065 \pm 0.002$ \\
\hline & & & & & $\begin{array}{l}\text { Total phenolic acids } \\
\text { Total flavonoids } \\
\text { Total phenolic compounds }\end{array}$ & $\begin{array}{l}22.1 \pm 0.1 \\
5.39 \pm 0.01 \\
27.48 \pm 0.09\end{array}$ \\
\hline
\end{tabular}

Table 2

Determined $\mathrm{GI}_{50}$ concentrations of the A. millefolium extracts.

\begin{tabular}{lll}
\hline Extract & \multicolumn{1}{c}{$\mathrm{GI}_{50}$ Concentrations $(\mu \mathrm{g} / \mathrm{mL})$ in different cell lines } \\
\cline { 2 - 3 } & $\mathrm{NCI}-\mathrm{H} 460$ & HCT-15 \\
\hline $\begin{array}{c}\text { A. millefolium hydroethanolic } \\
\text { extract }\end{array}$ & $187.3 \pm 25.7$ & $70.8 \pm 8.1$
\end{tabular}

$\mathrm{GI}_{50}$ corresponds to the mean \pm S.E. of at least three independent experiments, each of them carried out with duplicates. Doxorubicin was used as a positive control, with the following results having been obtained: $45.8 \pm 11.5 \mathrm{nM}$ in NCI-H460 cells and $293.3 \pm 7.2 \mathrm{nM}$ in HCT-15 cells. GI $_{50}$ refers to the concentration that inhibits $50 \%$ of cell growth. S.E. refers to standard error.

\section{Methods}

\subsection{Plant and preparation of the extract}

Achillea millefolium L. was collected in Cova de Lua, Bragança, as previously described by Dias et al. (Tozyo et al., 1994). The sample was lyophilized (FreeZone 4.5, Labconco, Kansas City, MO, USA), reduced to a fine powder $(\sim 20$ mesh), homogenized and conserved in deep freezing conditions $\left(-80^{\circ} \mathrm{C}\right)$ for further analysis.

The hydroethanolic extract was obtained by macerating the fine and lyophilized powder $(1.5 \mathrm{~g})$ with two subsequent portions of ethanol/ water $(80: 20, \mathrm{v} / \mathrm{v})$. Each portion was centrifuged at $150 \mathrm{rpm}$ for $1 \mathrm{~h}$ at room temperature (RT). The first portion was filtered and the solid residue was extracted again. Both filtered supernatants (Whatman No. 4 filter paper) were then evaporated under vacuum at $35^{\circ} \mathrm{C}$ (Büchi R-210, Flawil, Switzerland). The remaining water residue was lyophilized (FreeZone 4.5 model 7750031, Labconco, KS, USA). The resulting fine powder was homogenized and the crude extract was stored in the dark at RT until tested. Stock solutions of the plant extract were prepared in water and stored at $-20^{\circ} \mathrm{C}$ until further use.

\subsection{Phenolic characterization of the extract}

Dry lyophilized extract was dissolved in water/ethanol (80:20, v/v) in sonic bath at a final concentration of $5 \mathrm{mg} / \mathrm{mL}$, and filtered through a $0.22 \mu \mathrm{m}$ nylon filter for chromatographic analysis. A Dionex Ultimate 3000 UPLC (Thermo Scientific, San Jose, CA, USA) with a diode array detector (DAD, 280 and $370 \mathrm{~nm}$, as preference wavelengths) and coupled to a Linear Ion Trap LTQ XL mass spectrometer (Thermo Finnigan, San Jose, CA, USA) equipped with an electrospray ionization was used to perform the analysis (Bessada et al., 2016). The identification of phenolic compounds was achieved by comparing retention times, UV-Vis and mass spectra with available standard compounds. Otherwise, available data reported in the literature were applied to tentatively identify the compounds. Quantitative analysis was performed from a 5-level calibration curve $(2.5-100 \mu \mathrm{g} / \mathrm{mL})$ of each available phenolic standard constructed upon the UV signal: apigenin-6-C-glucoside (y = 246.05x-309.66; $\left.R^{2}=0.9994\right) ; \quad$ apigenin-7-O-glucoside ( $\left.\mathrm{y}=159.62 \mathrm{x}+70.50 ; R^{2}=0.999\right) ;$ caffeic acid $(\mathrm{y}=611.9 \mathrm{x}-4.5733$; $\left.R^{2}=0.999\right) ; 5-O-c a f f e o y l q u i n i c ~ a c i d\left(y=313.03 \mathrm{x}-58.20 ; R^{2}=0.999\right)$; kaempferol-3-O-glucoside ( $\mathrm{y}=288.55 \mathrm{x}-4.05 ; R^{2}=1$ ); kaempferol-3-Orutinoside $\quad\left(\mathrm{y}=239.16 \mathrm{x}-10.587 ; \quad R^{2}=1\right) ; \quad$ luteolin-6-C-glucoside (y = 508.54x-152.82; $\left.\quad R^{2}=0.997\right) ; \quad$ luteolin-7-O-glucoside (y $\left.=80.829 \mathrm{x}-21.291 ; \quad R^{2}=0.999\right) ; \quad$ quercetin-3-O-glucoside (y $\left.=253.52 \mathrm{x}-11.615 ; \quad R^{2}=0.999\right) \quad$ and quercetin-3-O-rutinoside ( $\left.\mathrm{y}=281.98 \mathrm{x}-0.3459 ; R^{2}=1\right)$. Identified phenolic compounds with unavailable commercial standard were quantified via the calibration curve of the most similar standard available. The analyses were carried out in triplicate and the results were expressed as mean values and standard deviations (SD), in $\mathrm{mg} / \mathrm{g}$ of lyophilized extract. 


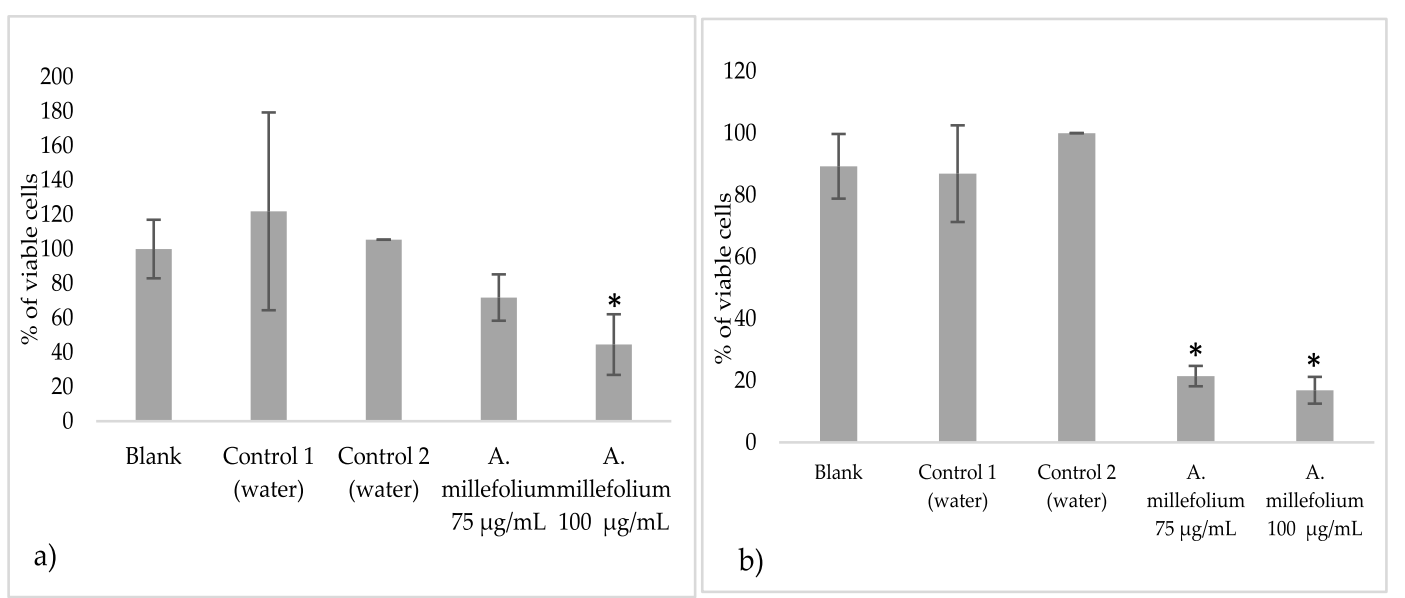

Fig. 1. Effect of A. millefolium hydroethanolic extract on NCI-H460 (a) and HCT-15 (b) viable cell number. Cells were treated for $48 \mathrm{~h}$ with medium (Blank), extract $(75 \mu \mathrm{g} / \mathrm{mL}$ and $100 \mu \mathrm{g} / \mathrm{mL}$ ) or with the corresponding water volumes (control 1 and control 2, respectively). Viable cell number was measured with the Trypan blue exclusion assay.

\subsection{Cell culture}

Two human tumor cell lines were used in this study: NCI-H460 (non-small cell lung cancer, a kind gift from NCI, USA), and HCT-15 (human colorectal adenocarcinoma). The cells were regularly kept in RPMI-1640 medium supplemented with Ultraglutamine I and $25 \mathrm{mM}$ HEPES (Lonza) and Fetal Bovine Serum (FBS, Biowest). The FBS was used at a concentration of $5 \%(\mathrm{v} / \mathrm{v})$ for the Sulforhodamine B (SRB) assay and of $10 \%(\mathrm{v} / \mathrm{v})$ for all the remaining assays. The cells were maintained at $37^{\circ} \mathrm{C}$ in a humidified incubator with $5 \% \mathrm{CO}_{2}$. The experiments described in the next sections were performed only when exponentially growing cells presented more than $95 \%$ viability determined with the Trypan blue exclusion assay. All cell lines were genotyped and regularly monitored for mycoplasma contamination by PCR.

\subsection{Cell growth inhibition assay}

In order to determine the in vitro cytotoxicity of the A. millefolium extract, the SRB (sulforhodamine B) assay was carried out in the three human tumor cell lines mentioned above.

Cells were plated in 96-well plates at an optimal density previously determined to allow exponential cell growth during the assay $\left(5.0 \times 10^{4}\right.$ cells $/ \mathrm{mL}$ for $\mathrm{H} 460$ cells and $1.0 \times 10^{5}$ cells $/ \mathrm{mL}$ for HCT15 cells) (Santos et al., 2013). Cells were treated $24 \mathrm{~h}$ later with five serial dilutions of the extract, ranging from $400 \mu \mathrm{g} / \mathrm{mL}$ to $25 \mu \mathrm{g} / \mathrm{mL}$. As positive control, doxorubicin was used in concentrations ranging from $150 \mathrm{nM}$ to $9.37 \mathrm{nM}$. As negative control, water was used (in a volume corresponding to the one used when testing the highest concentration of the extract). Two plates were prepared: one to be analyzed immediately after extract addition (T0 plate) and another one to be analyzed $48 \mathrm{~h}$ after extract addition (T48 plate). After $48 \mathrm{~h}$ of incubation for the T48 plate (or immediately for the T0 plate), cells were fixed by adding ice-cold 10\% (w/v) trichloroacetic acid (TCA) (Panreac, Barcelona, Spain) and stained with 1\% SRB (Sigma Aldrich, St. Louis, MO, USA) in $1 \%(\mathrm{v} / \mathrm{v})$ of acetic acid (Sigma Aldrich, St. Louis, MO, USA). The bound dye was solubilized by adding $10 \mathrm{mM}$ Tris base solution (Sigma Aldrich, St. Louis, MO, USA) and the absorbance was measured at $510 \mathrm{~nm}$ in a microplate reader (BioTek ${ }^{\circ}$ Synergy MX, Winooski, VT, USA). The $\mathrm{GI}_{50}$ concentration of the A. millefolium extract was determined for each cell line tested (Vichai and Kirtikara, 2006).

\subsection{Preparation of cells for further analysis}

In order to analyze the effect of the extract on cell cycle profile, apoptosis, and on the expression of selected proteins, the NCI-H460 and HCT-15 were plated at a concentration of $1.0 \times 10^{5}$ cells/well and $2.0 \times 10^{5}$ cells/well, respectively, in 6 -well plates. After $24 \mathrm{~h}$, cells were treated with the A. millefolium extract at two different concentrations, $75 \mu \mathrm{g} / \mathrm{mL}$ and $100 \mu \mathrm{g} / \mathrm{mL}$. Medium and water were added to Blank and control cells, respectively, at the same volumes as the ones used when testing the 2 extract concentrations (control 1 corresponding to the $75 \mu \mathrm{g} / \mathrm{mL}$ extract; control 2 corresponding to the $100 \mu \mathrm{g} / \mathrm{mL}$ extract). After $48 \mathrm{~h}$ treatment, cells were trypsinized and centrifuged at $1200 \mathrm{rpm}$ for $5 \mathrm{~min}$. The percentage of viable cells was determined with the trypan blue exclusion assay.

\subsubsection{Analysis of cell cycle profile}

Cells were washed with a Phosphate Buffer Solution (PBS) (Sigma Aldrich, St. Louis, MO, USA), fixed with ice-cold 70\% ethanol (Sigma Aldrich, St. Louis, MO, USA) and stored at $4{ }^{\circ} \mathrm{C}$ for at least $12 \mathrm{~h}$. Cells were then centrifuged for $5 \mathrm{~min}$ at $290 \times \mathrm{g}$ and pellets were re-suspended in a solution of PBS containing $5 \mu \mathrm{g} / \mathrm{mL}$ propidium iodide (Sigma Aldrich, St. Louis, MO, USA) and $0.1 \mathrm{mg} / \mathrm{mL}$ RNase A (Sigma Aldrich, St. Louis, MO, USA). Cellular DNA content analysis was performed by flow cytometry (BD Accuri ${ }^{\mathrm{TM}} \mathrm{C} 6$ Flow cytometer, USA) and the percentage of cells in the G0/G1, S and G2/M phases of the cell cycle was determined following cell debris and aggregates exclusion and plotting at least 10,000 events per sample, as previously described (Vasconcelos et al., 2000). All the results were analyzed using the FlowJo software (version 7.6.5, Tree Star, Inc., Ashland, USA).

\subsubsection{Analysis of apoptosis}

Cell pellets were washed and re-suspended in PBS. After centrifugation at $290 \times \mathrm{g}$, cells were analyzed for apoptosis levels with the Annexin V-FITC Apoptosis Detection Kit (eBioscience), as previously described (Vaz et al., 2012). All the samples were then analyzed by flow cytometry (BD Accuri ${ }^{\mathrm{TM}}$ C6 Flow cytometer, USA) plotting at least 10,000 events per sample. Results were analyzed using the FlowJo software (version 7.6.5, Tree Star, Inc., Ashland, USA).

\subsubsection{Protein expression analysis}

Cellular pellets were washed in PBS and Winman's buffer (1\% NP40, 0.1 M Tris- $\mathrm{HCl} \mathrm{pH} 8.0,0.15 \mathrm{M} \mathrm{NaCl}$ and $5 \mathrm{mM}$ EDTA) supplemented with protease inhibitor cocktail (Roche, Indianopolis, USA) was used to lyse the cells. The total protein content of lysates was quantified with a modified Lowry protocol using the DC ${ }^{\mathrm{TM}}$ Protein Assay kit (Bio-Rad, Hercules, CA, USA), following manufacturer's instructions. Protein lysates were then loaded on a $12 \%$ SDS-PAGE gel and transferred into a nitrocellulose membrane (GE Healthcare Life science, Cleveland, $\mathrm{OH}$, 

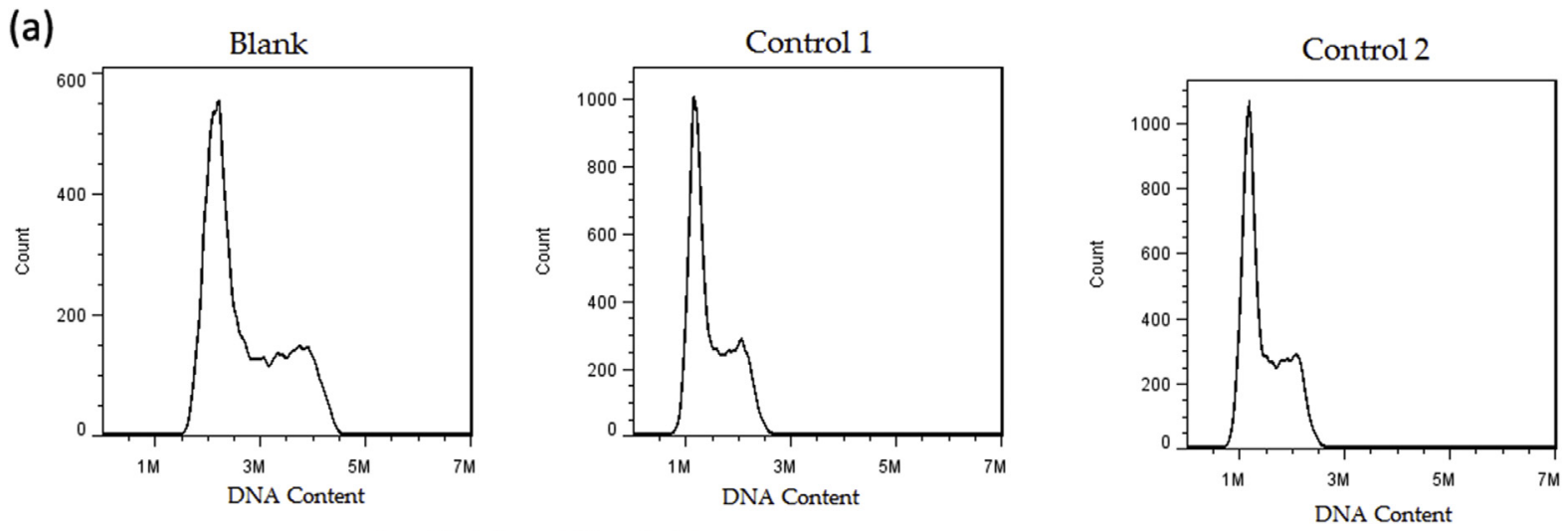

A. millefolium $(75 \mu \mathrm{g} / \mathrm{mL})$
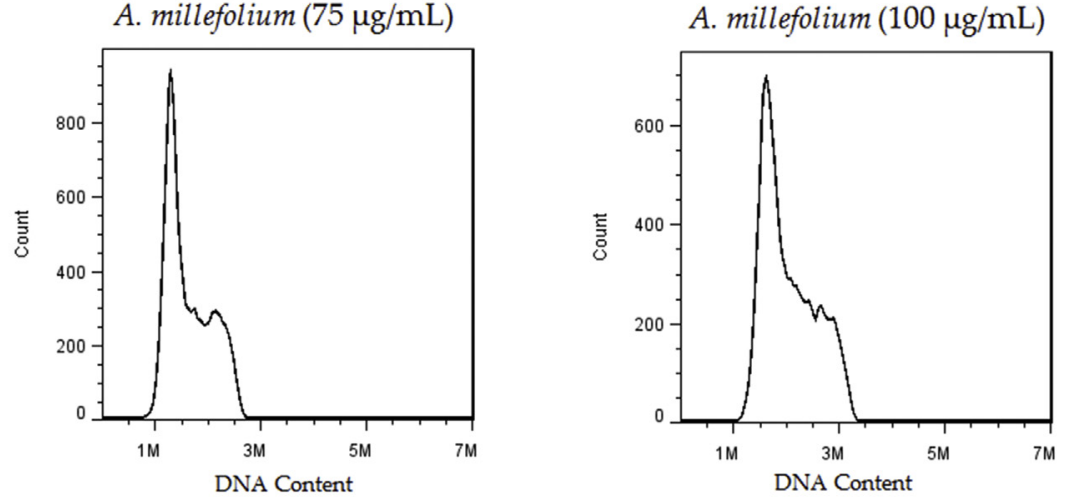

60,00

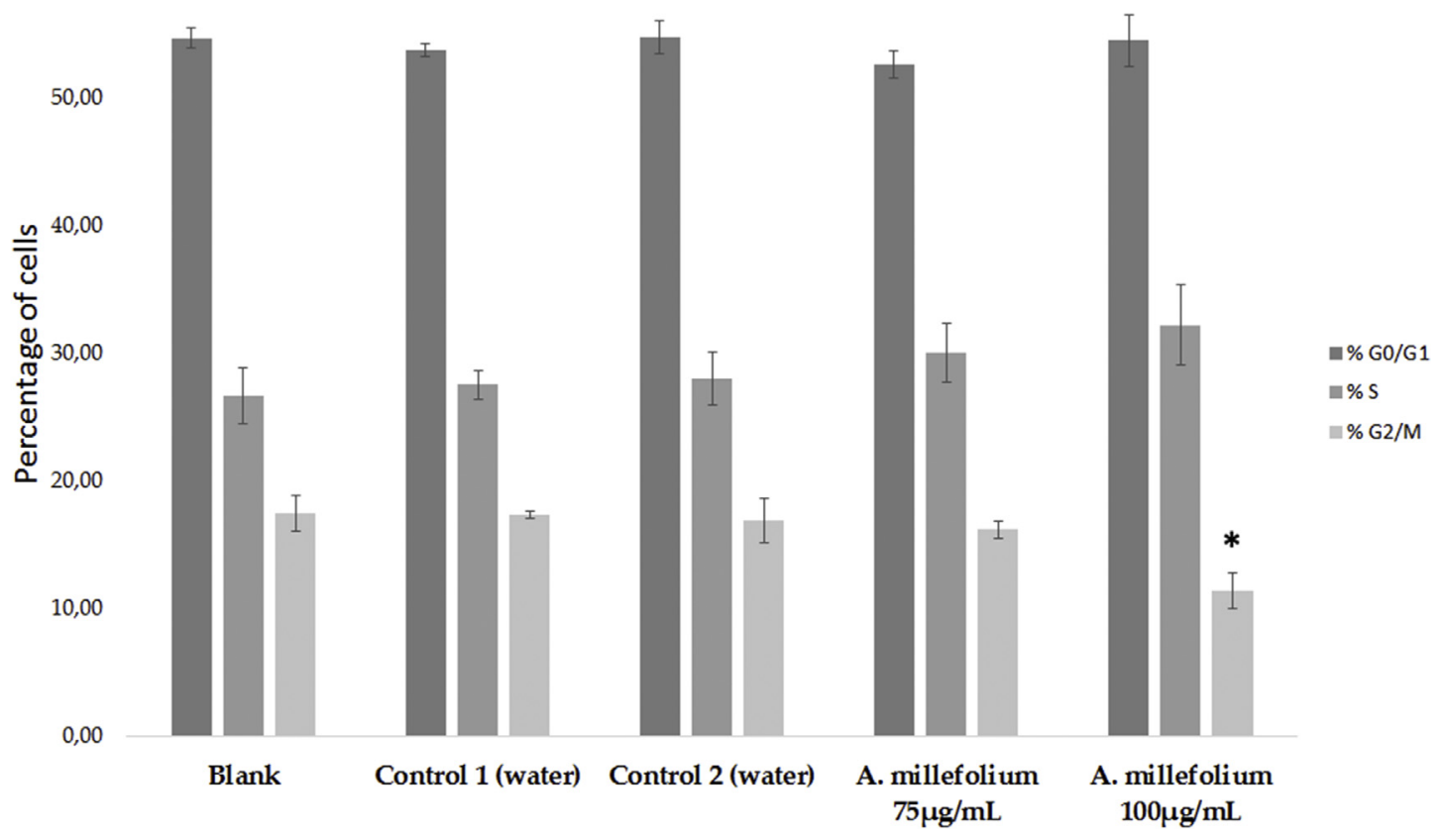

Fig. 2. Cell cycle distribution of NCI-H460 (a) and HCT-15 (b) cells treated with the hydroethanolic extract of A. milefolium. Cells were treated with A. milefolium $(75 \mu \mathrm{g} / \mathrm{mL}$ or $100 \mu \mathrm{g} / \mathrm{mL}$ ) during $48 \mathrm{~h}$. Water (in the same volumes as the used for each treatment) was included as controls. Upper panels correspond to the histograms with cell cycle profile, following the exclusion of cellular aggregates and debris. Lower panels correspond to the \% of cells in different cell cycle phases. Results are the mean \pm SE of 3 independent experiments. * $p \leq 0.05$ between each treatment and the respective control.

USA). Membranes were then blocked in TBS-T [Tris-buffered saline solution with $0.1 \%$ Tween 20 (Promega, Fitchburg, USA)], containing $5 \%(\mathrm{w} / \mathrm{v})$ non-fat dry milk (Nestlé, São Paulo, Brazil) for at least $30 \mathrm{~min}$. The following primary antibodies were used: rabbit anti-PARP1 (1:2000, sc-7150, Santa Cruz Biotechnology, Heidelberg, Germany), mouse anti-p53 (1:200, sc-126, Santa Cruz Biotechnology), mouse anti- caspase 3 (1:1000, sc-7272, Santa Cruz Biotechnology); mouse anti-p21 (1:250, Ab-1, Calbiochem, USA), mouse anti-XIAP (1:1000, 2042, Cell Signaling Technology, Danvers, MA, USA), mouse anti-tubulin (1:10000, Sigma Aldrich, St. Louis, MO, USA) and goat anti-actin (1:2000, sc-1616, Santa Cruz Biotechnology). The secondary antibodies used were: anti-rabbit IgG-HRP, anti-mouse IgG-HRP and anti-goat IgG- 
(b)

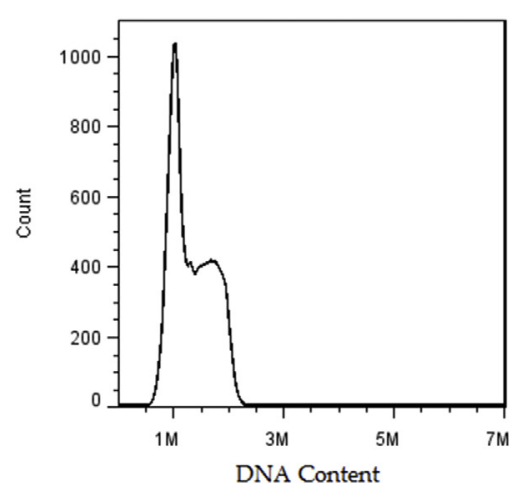

Control 1

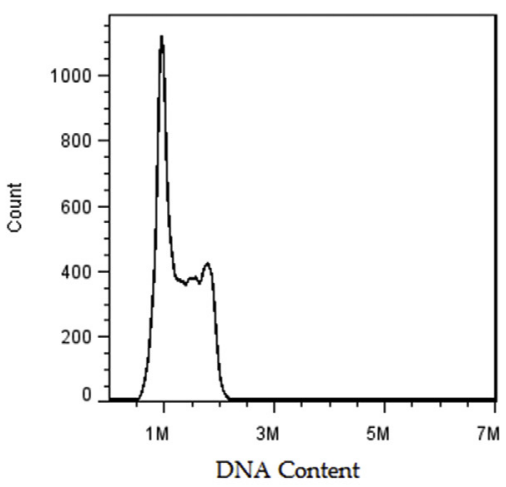

Control 2

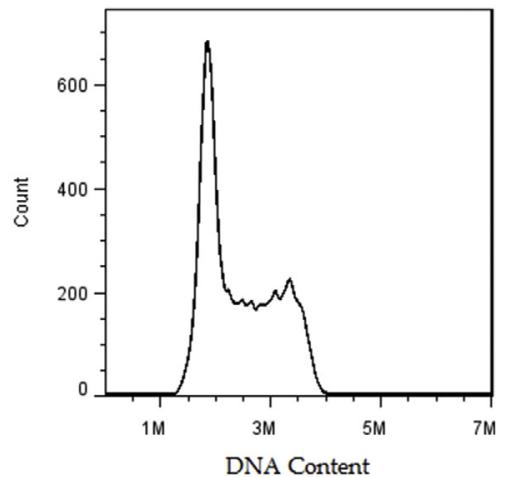

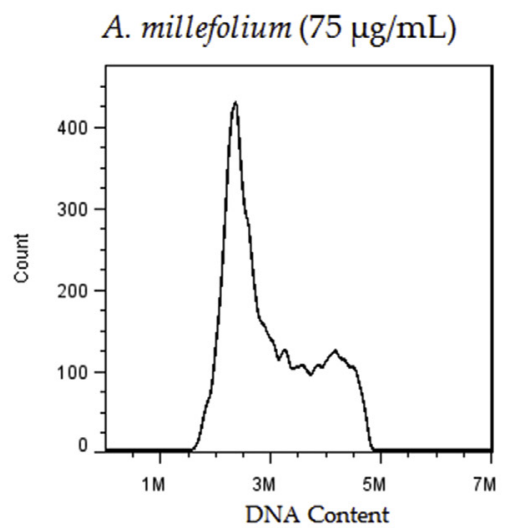
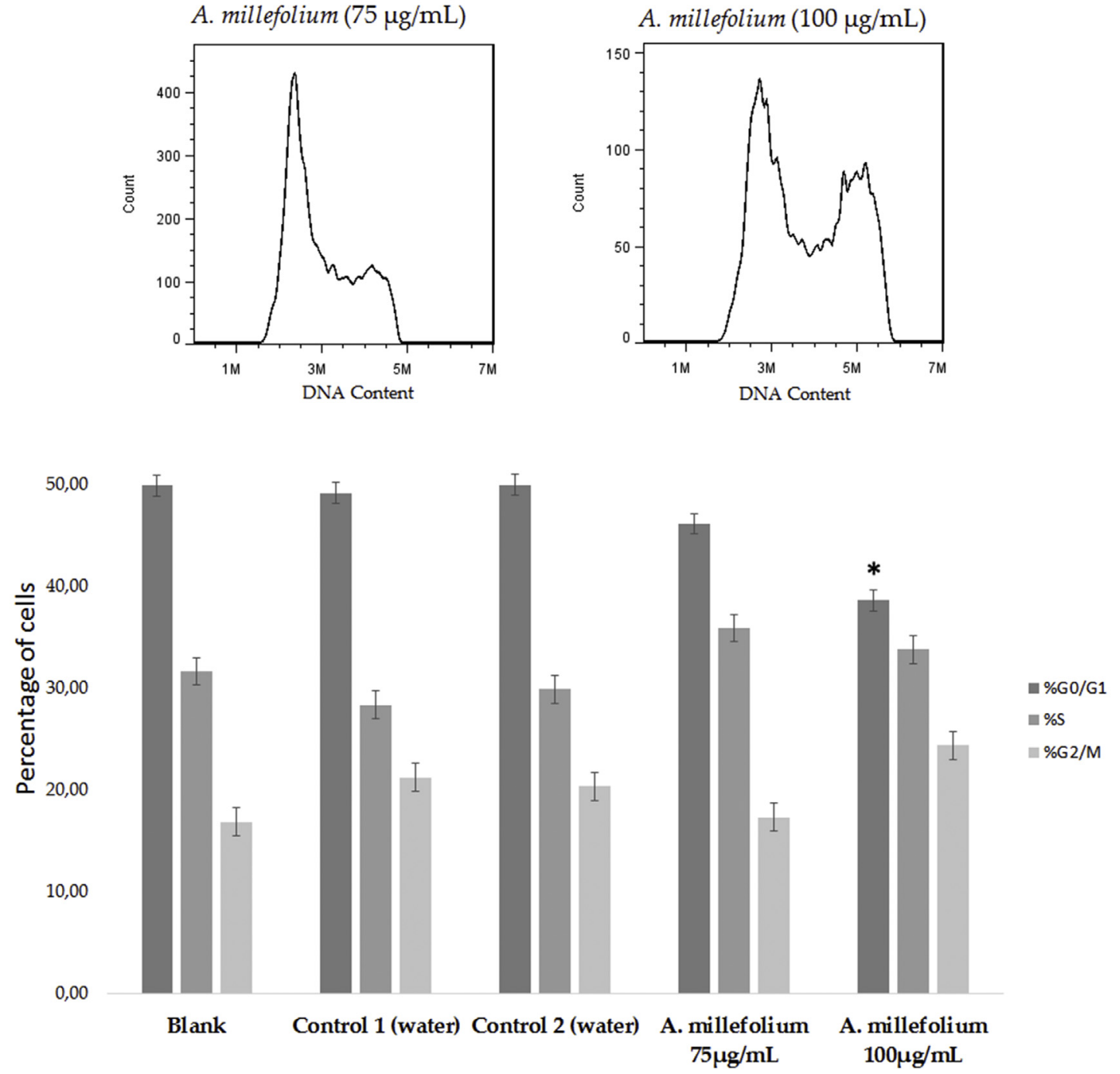

Fig. 2. (continued)

HRP (1:2000, Santa Cruz Biotechnology). The Amersham ${ }^{\mathrm{TM}}$ ECL Western Blotting Detection Reagents (GE Healthcare, Wisconsin, USA), the High Performance Chemiluminescence Film (GE Healthcare, Wisconsin, USA), and the Kodak GBX developer and fixer (Sigma Aldrich, St. Louis, MO, USA) were used for signal detection (Lopes-Rodrigues et al., 2016).

\subsection{Statistical analysis}

The results of at least three independent experiments were statistically analyzed using the two-tailed paired Student's t-test.

\section{Results}

\subsection{Phenolic compounds in A. millefolium hydroethanolic extract}

Table 1 presents the chromatographic characteristics of the phenolic compounds found in A. millefolium hydroethanolic extract. Twentyeight phenolic compounds were detected, being identified 8 phenolic acid derivatives (compounds 1, 2, 3, 4, 16, 19, 20 and 22) and 20 flavonoid glycoside derivatives (compounds $5-15,17,18,21,23-28$ ). Phenolic acids were the main class of polyphenols present, consisting of 


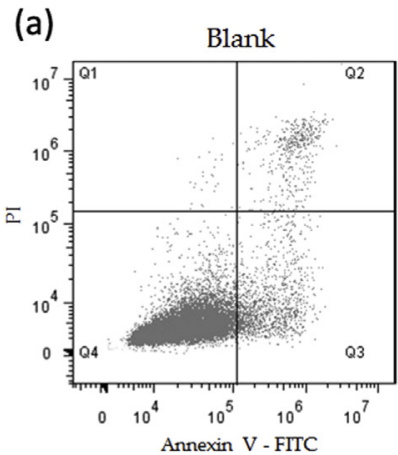

A. millefolium $(75 \mu \mathrm{g} / \mathrm{mL})$

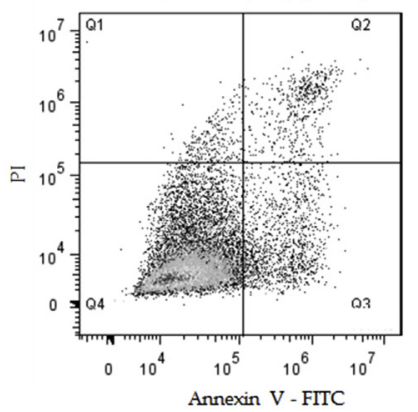

Control 1

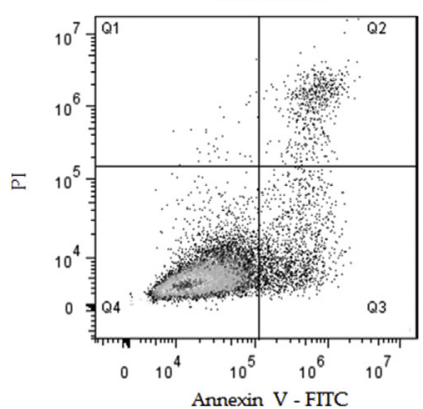

Control 2

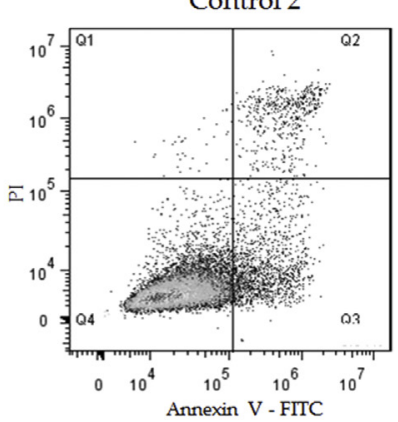

A. millefolium $(100 \mu \mathrm{g} / \mathrm{mL})$

(b)
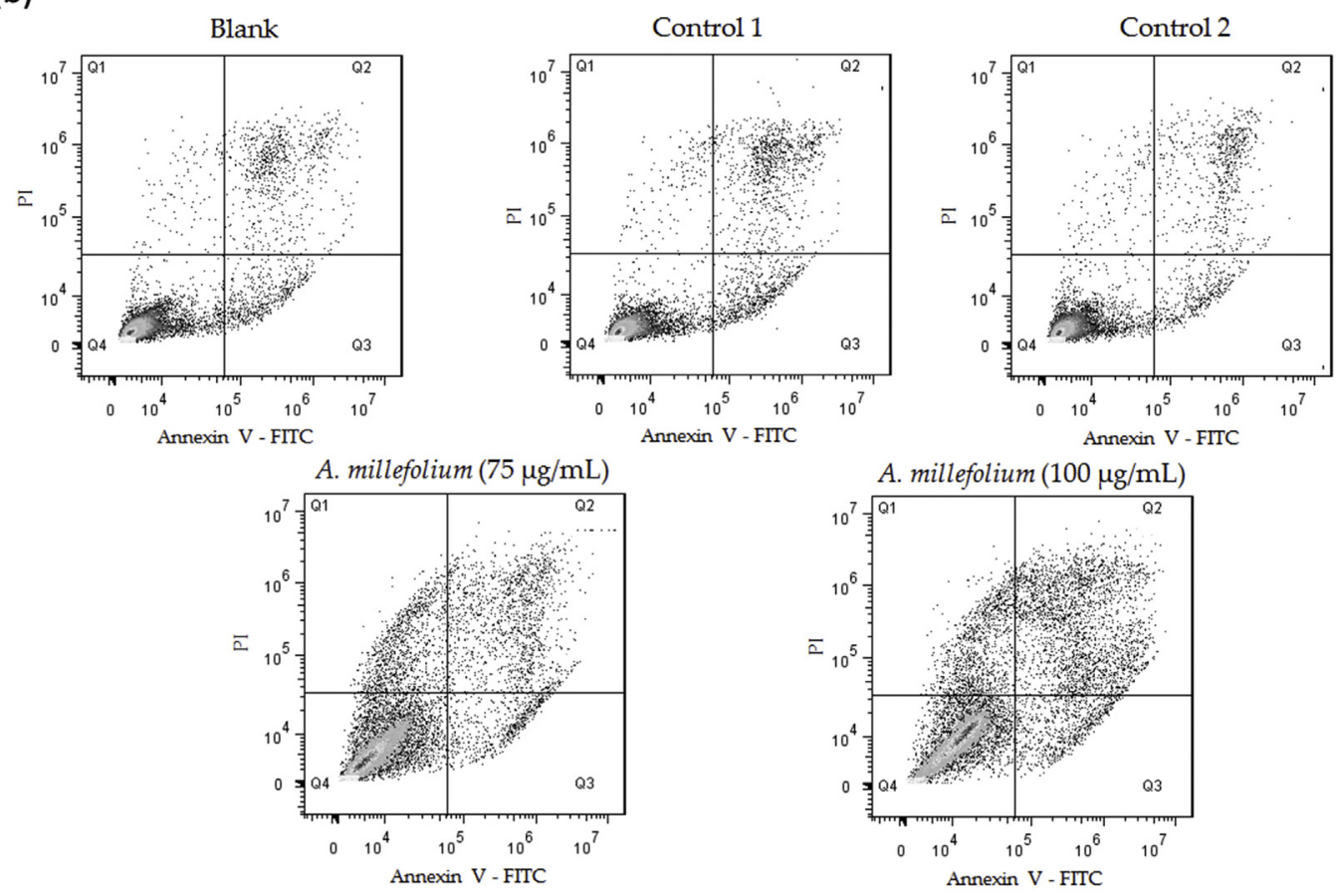

(c)

\begin{tabular}{|c|c|c|}
\hline \multirow{2}{*}{ Samples } & \multicolumn{2}{|c|}{$\%$ of cells in apoptosis } \\
\cline { 2 - 3 } & NCI-H460 & HCT-15 \\
\hline Blank & $13.25 \pm 1.53$ & 9.82 \\
\hline Control 1 & $11.26 \pm 1.67$ & $9.21 \pm 0.74$ \\
\hline Control 2 & $9.81 \pm 1.18$ & $8.96 \pm 1,69$ \\
\hline A. millefolium $\mathbf{( 7 5} \boldsymbol{\mu g} / \mathrm{mL})$ & $14.24 \pm 1.81$ & $18.23 \pm 3.47$ \\
\hline A. millefolium $(\mathbf{1 0 0} \boldsymbol{\mu g} / \mathrm{mL})$ & $16.91 \pm 1.63 *$ & $38.96 \pm 8.35^{*}$ \\
& & \\
\hline
\end{tabular}




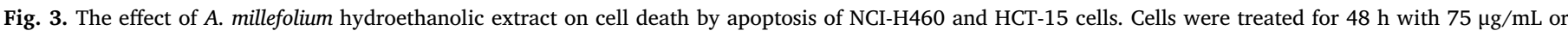

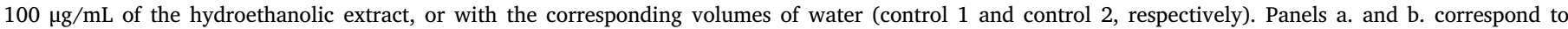

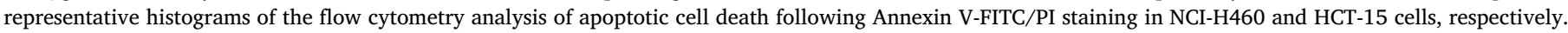

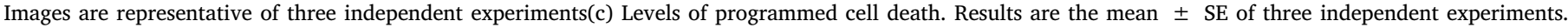
*p $\leq 0.05$ treatment vs the respective control.
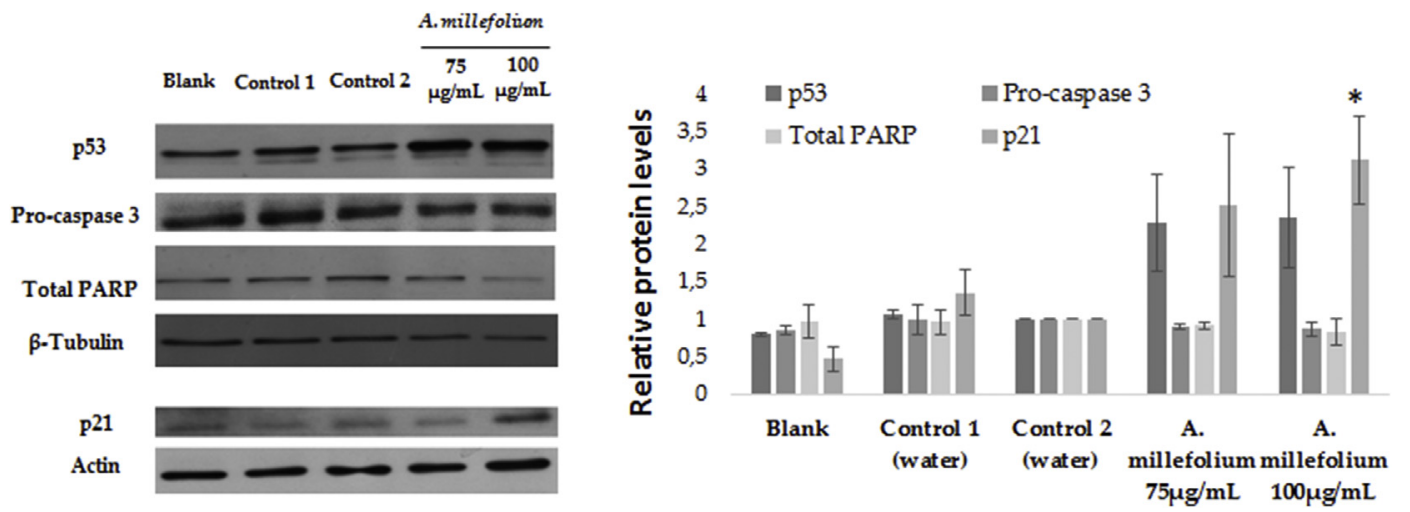

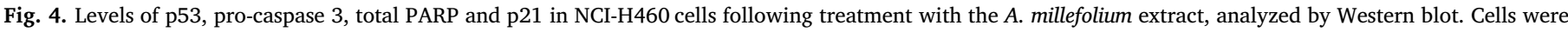

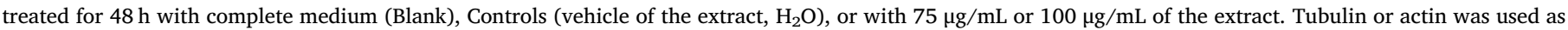

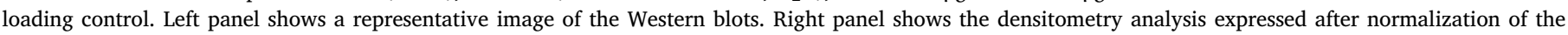

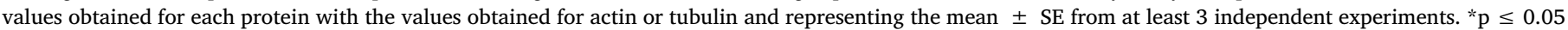
between treatment and Control 2.
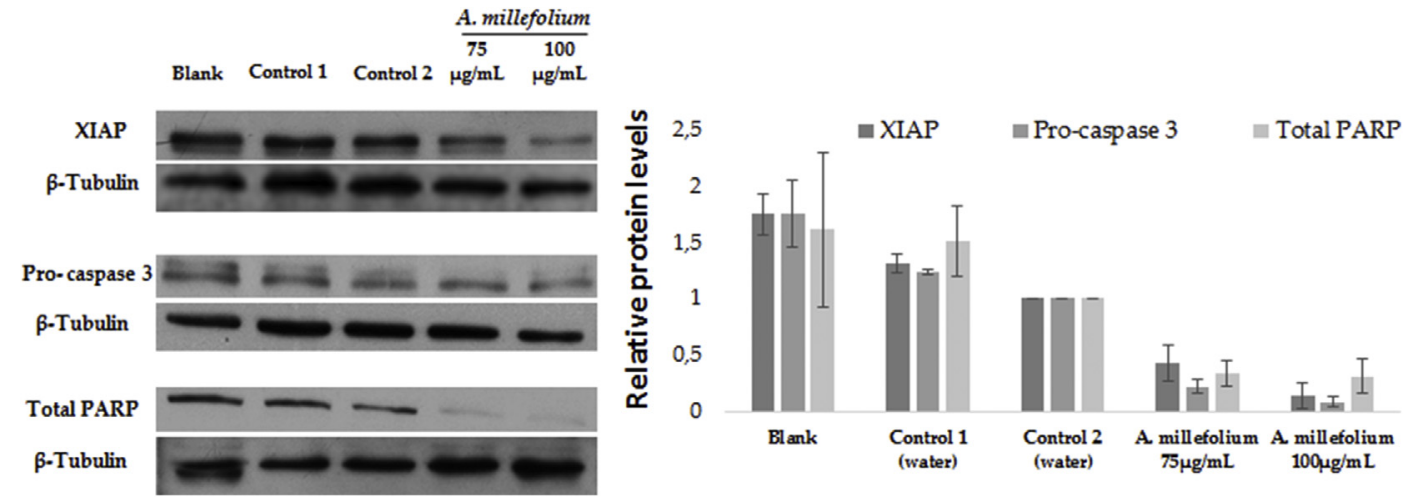

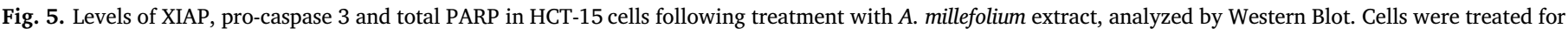

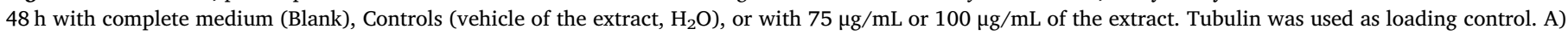

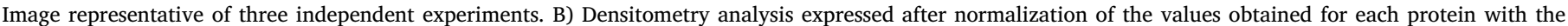
values obtained for tubulin and representing the mean \pm SEM from 3 independent experiments. ${ }^{*} \mathrm{p} \leq 0.05$ treatment vs Control 2 .

hydroxycinnamic acid, being chlorogenic acid derivatives the major compounds present. Regarding flavonoids, 11 were identified as flavones, mainly apigenin and luteolin glycoside derivatives, and 9 as flavonols being quercetin, kaempferol and isorhamnetin glycoside derivatives the main aglycones present. These compounds were previously identified and described by Dias et al. for aqueous and methanolic extracts of the same plant species (Dias et al., 2013).

cis and trans 3,5-O-Dicaffeoylquinic acid, followed by 5-O-caffeoylquinic acid, were the main phenolic acids, accounting to $66 \%$ of the total phenolic compounds. While, luteolin- $O$-acetylhexoside and apigenin-O-acetylhexoside were the main flavonoids, consisting in $9 \%$ of the polyphenols content. These compounds have been previously described to have cytotoxic activities (Costa et al., 2014; In et al., 2016; Lin et al., 2015; Murad et al., 2015).

\subsection{The A. millefolium hydroethanolic extract inhibited the growth of human tumor cell lines}

A screening of the A. millefolium hydroethanolic extract was performed with the sulforhodamine B assay in two human tumor cell lines:
NCI-H460 and HCT-15. Results (Table 2) showed an inhibitory effect of this plant extract on the growth of all the tested cell lines. The $\mathrm{GI}_{50}$ (concentration which inhibits the cell growth of $50 \%$ of cells) obtained was 187.3 and 70.8 for NCI-H460 and HCT-15 cells, respectively. This effect was more potent in the colon cancer cell line, and secondly in the lung cancer cell line. This bioactivity could be related to the high percentage of phenolic acids, mainly chlorogenic acid derivatives, accounting to $80 \%$ of the total phenolic composition present in the extracts. Chlorogenic acids have been previously described to have antiproliferative activity against several cell lines (Costa et al., 2014; In et al., 2016; Lin et al., 2015; Murad et al., 2015). Based on this, the NCIH460 and the HCT-15 cell lines were further studied in order to unravel the mechanism of action of this plant extract.

\subsection{The A. millefolium hydroethanolic extract reduced the number of viable cells}

In order to further confirm that this extract had a cell growth inhibition effect, the viable cell number was analyzed with the Trypan Blue exclusion assay in the colon and lung cancer cell lines. The number 
of viable cells was reduced when cells were treated for $48 \mathrm{~h}$ with $A$. millefolium $(75 \mu \mathrm{g} / \mathrm{mL}$ and $100 \mu \mathrm{g} / \mathrm{mL})$. As previously observed with the SRB assay, the extract was more potent in the HCT-15 cell line. In the NCI-H460 cells, when compared with the blank cells the extract caused a reduction of $28 \%$ and $55 \%$ in the viable cell number when tested at concentrations of $75 \mu \mathrm{g} / \mathrm{mL}$ and $100 \mu \mathrm{g} / \mathrm{mL}$, respectively (Fig. 1a). In the HCT- 15 cells, the same concentrations caused a more pronounced reduction in the number of viable cells, of $75 \%$ and $82 \%$ respectively (Fig. 1b)

\subsection{The A. millefolium hydroethanolic extract interfered with the cell cycle} progression

In order to unravel the molecular pathways involved in the growth inhibitory effect of the A. millefolium extract in both the colon and lung cancer cell lines, the cell cycle profile was analyzed by flow cytometry following incubation with propidium iodide. In NCI-H460 cells, the extract $(100 \mu \mathrm{g} / \mathrm{mL})$ caused a statistically significant decrease of $6.0 \%$ in the G2/M phase of the cell cycle when compared to Control 2 cells (Fig. 2a). In addition, this concentration caused a slight increase (nonstatistically significant) in the \% of cells in the S phase of the cell cycle, when compared to control treatments.

On the other hand, treatment of HCT-15 cells with A. millefolium $(100 \mu \mathrm{g} / \mathrm{mL})$ caused a statistically significant decrease (of $11.4 \%$ ) on the number of cells in the G1 phase of the cell cycle, when compared to Control 2 and a slight increase (non-statistically significant, of 4\%) in the number of cells in G2/M (Fig. 2b).

\subsection{The A. millefolium hydroethanolic extract induced cell death in the NCI-H460 and HCT-15 cells}

The effect of this plant extract in programmed cell death by apoptosis was also analyzed in both the lung and colon cell lines, with the Annexin-V and PI protocol. The obtained results (Fig. 3) showed that this extract when used at a concentration of $100 \mu \mathrm{g} / \mathrm{mL}$ caused an increase in the \% of cells undergoing apoptosis in both cell lines, when compared to the respective control treatments. Moreover, the effect was more pronounced in the HCT- 15 cell line, which is in agreement with the cell growth and viability results previously obtained. Indeed, in the HCT-15 cell line, a lower concentration of extract $(75 \mu \mathrm{g} / \mathrm{mL})$ also induced apoptosis, even though this increase was not considered statistically significant.

3.6. The A. millefolium hydroethanolic extract alters the expression levels of proteins involved in cell cycle and apoptosis in the NCI-H46O and HCT15 cells

Considering the here obtained results, showing effect on cell cycle profile and apoptosis, the expression of some proteins related to these pathways was studied in both cell lines, following treatment with $75 \mu \mathrm{g} / \mathrm{mL}$ and $100 \mu \mathrm{g} / \mathrm{mL}$ of the extract. Interestingly, the obtained results were different between the two cell lines.

In the NCI-H460 cells, results showed that treatment with the $A$. millefolium extract caused an increase in the levels of p53 and p21, and a slight decrease in the levels of pro-caspase 3 and total PARP (Fig. 4). However, this effect was only verified with the highest concentration tested $(100 \mu \mathrm{g} / \mathrm{mL})$ and was considered statistically significant only for p21. In addition, no statistically significant effect was seen in the expression of XIAP (even though a slight increase was detected, data not shown).

In the HCT-15 cells, results revealed that the extract caused a reduction in the expression levels of XIAP, pro-caspase 3 and total PARP (Fig. 5). These results were observed at both concentrations tested $(75 \mu \mathrm{g} / \mathrm{mL}$ and $100 \mu \mathrm{g} / \mathrm{mL}$ ) and were considered statistically significant for all the proteins analyzed: XIAP, pro-caspase 3 and total PARP. In addition, no effect was seen on p53 and p21 (data not shown) (see
Fig. 5).

\section{Discussion}

This work demonstrates for the first time that a hydroethanolic extract of $A$. millefolium has antitumor potential by interfering with the progression of the cell cycle and causing apoptosis, this could be due to the fact that this extract has a high concentration in chlorogenic acid derivatives (mainly 3,5-O-dicaffeoylquinic acid and 5-O-caffeoylquinic), known to have a high bioactive capacity, especially in the inhibition of cell growth (Anantharaju et al., 2016; Gouthamchandra et al., 2017). This extract, rich in chlorogenic acid derivatives, was more potent in the HCT15 cell line than in the NCI-H460 cell line, suggesting a different mechanism of action in the two cell lines, which could be an effect of polyphenol composition present in the extract. There are few studies that have also reported the therapeutic efficacy of chlorogenic acids derivatives for treating cancers, revealing that these hydroxicinnamic acid derivatives down modulate MAPK and AKT signaling pathways to inactivate the NF-k $\beta$, AP-1 and STAT3 in lung adenocarcinomas (Tsai et al., 2013), thus phenolic acids, especially hydroxicinnamic acid derivatives are known to play a crucial role in blocking oncogenic pathways to inhibit cancer progression (Anantharaju et al., 2016). Moreover, a number of pre-clinical and phase I clinical studies have shown that treatment with chlorogenic acid derivatives have shown beneficial effects in colon, lung and brain cancer, breast tumours, and chronic myelogenous leukemia (Bandyopadhyay et al., 2004; Belkaid et al., 2006; Xu et al., 2013).

Indeed, in the two cells lines that were used (the NCI-H460 and the HCT-15), the extract interfered with distinct phases of the cell cycle progression. In addition, the extract caused a stronger effect on apoptosis in the HCT- 15 cells. This could be related to the fact that the HCT15 cell line has an heterozygous mutation in the p53 gene (Santos et al., 2013), whereas the NCI-H460 cell line has wild-type (wt) p53. The wt p53 is a well-known tumor suppressor gene that regulates several processes in cells, such as cell cycle arrest, DNA repair and apoptosis. Nevertheless, when p53 is mutated, it does not carry this role as tumorsuppressor gene (Merkel et al., 2017; Schmidt et al., 2017).

In the NCI-H460 cells in which the p53 gene is wild-type, treatment with the extract caused an increase in the levels of p53 and also of p21, a protein described as a cell cycle inhibitor (El-Deiry, 2016) and regulated directly by p53 (Vogelstein et al., 2000). In addition, in this cell line the extract caused an increase in apoptosis levels, as verified by the Annexin V/PI results and confirmed by the verified decrease in the cellular levels of pro-caspase 3 (suggesting that caspase 3 was activated (Ashkenazi and Salvesen, 2014)) and of total PARP (known to be correlated with the late stages of the apoptotic process (Duriez and Shah, 1997)). Therefore, these results suggest that the effect of the extract in this cell line is mediated via p53. This activity could be attributed to the high concentration in chlorogenic acid derivative, which may cause the increase of apoptosis levels.

In the HCT-15 cells which have mutant p53, no effect was verified in the levels of p53 or p21 upon treatment with the extract (results not shown). In addition, treatment with this extract caused a more potent effect in cell cycle and apoptosis. Nonetheless, the effect on the progression of the cell cycle was not mediated in the same way. The extract caused a decrease in the G0/G1 and a slight increase in the G2/M phases of the cell cycle, which are not compatible with a p53-mediated effect. Therefore, as expected, the effect in this cell line does not seem to involve p53. The mechanism of action of this extract in this cell line involved a very strong increase in apoptosis, as verified by the Annexin $\mathrm{V} / \mathrm{PI}$ results and from the decrease in the expression levels of pro-caspase 3 and total PARP. In addition, in this cell line the extract caused a pronounced decrease in the cellular levels of XIAP. The XIAP belongs to a family of proteins named inhibitor of apoptosis proteins (IAP), which are capable of regulating several cell signaling pathways involved in numerous processes, such as cell proliferation, apoptosis, 
differentiation, migration and pro-inflammatory and immune responses. Since XIAP is involved in such cellular processes, it has been largely studied as a target for new therapies, particularly in situations of resistance to apoptosis and resistance to anticancer therapy (Budhidarmo and Day, 2015; Philchenkov and Miura, 2016; Pluta et al., 2015). Indeed, various inhibitors of XIAP (either antisense oligonucleotides or small molecules) have been studied in pre-clinical and clinical trials (Flygare et al., 2012; Lee et al., 2016; Mahadevan et al., 2013). The results here presented show that this extract reduces XIAP protein levels in the HCT-15 cells, which is possibly the main mechanism of action of this extract in this cell line. These findings could be related to the main metabolites present in the extract, which are mainly constituted with chlorogenic acid derivatives. Indeed, another inhibitor of XIAP was previously documented to induce apoptosis and to arrest cell cycle in G2/M (Langemann et al., 2017).

Other studies had shown the antitumor potential of other extracts of A. millefolium in various human tumor cell lines. Indeed, a chloroformsoluble extract of this plant exerted tumor cell proliferation inhibitory activities on HeLa and MCF-7 cells, and also a moderate effect on A431 cells (Csupor-Loffler et al., 2009). Moreover, previous studies have shown that methanolic, infusion and decoction extracts of $A$. millefolium reduced the growth of five different cancer cell lines. In that study, the infusion extract was the most potent one, in a breast cancer cell line (MCF-7), therefore presenting the lowest $\mathrm{GI}_{50}$ (Dias et al., 2013).

The chemical composition of several extracts (methanolic, infusion and decoction) from A. millefolium was studied and revealed that these are composed by phenolic acid derivatives, mainly caffeoylquinic acid derivatives and flavones (Dias et al., 2013). Both caffeoylquinic acid derivatives and flavones are recognized for their antioxidant, antitumor and anti-inflammatory properties (Costa et al., 2014; In et al., 2016; Lin et al., 2015; Murad et al., 2015). Therefore, the composition of different extracts (hydroalcoholic, methanolic, aqueous, infusion and decoction) suggests an antioxidant potential and this activity was demonstrated by several authors, using different assays (Candan et al., 2003; Dias et al., 2013; Kintzios et al., 2010; Vitalini et al., 2011). In addition, some sesquiterpenoids were isolated as methyl esters from Achillea millefolium and were active against mouse P-388 leukemia cells in vivo (Tozyo et al., 1994).

\section{Conclusion}

The presented results proved that the A. millefolium hydroethanolic extract caused reduction of cell growth in the cell lines tested. This effect was more potent in the colorectal cancer cell line (HCT-15, with mutant p53) but also had a strong effect in the lung cancer cell line (NCI-H460, with wild-type p53). This could be due to the high concentration in chlorogenic acid derivatives, which have shown that they can induce cytotoxic effects in many human cancer cell lines.

This extract, rich in chlorogenic acid derivatives, interfered with the cell cycle progression and induced apoptosis in those two cell lines. However, the mechanism of action was different in the two cell lines, possibly due to the fact that one had wild-type p53 and the other one had mutant p53. The effect in the NCI-H460 cell line was possibly mediated via p53, whereas the effect in the HCT-15 cell line was, at least in part, due to a downregulation of XIAP levels. It would be interesting to further analyze the biochemical composition of extract and to isolate the different compounds present in this extract in order to identify potent inhibitors of XIAP. Therefore, this work enhances the interest of this plant extract as a possible source of new natural bioactive compounds, particularly of XIAP inhibitors.

\section{Conflicts of interest}

The authors declare no conflict of interest.

\section{Acknowledgements}

This work was funded by FEDER - Fundo Europeu de Desenvolvimento Regional através do COMPETE 2020 - Programa Operacional para a Competitividade e Internacionalização (POCI), Portugal 2020, and by portuguese fundings through FCT - Fundação para a Ciência e a Tecnologia/Ministério da Ciência, Tecnologia e Inovação, no âmbito do projeto "Instituto de Investigação e Inovação em Ciências da Saúde (POCI - 01-0145 -FEDER - 007274)". The authors are also grateful to FCT and FEDER under Programme PT2020 for financial support to CIMO (UID/AGR/00690/2013) and L. Barros contract; and to FEDER-Interreg España-Portugal programme for financial support through the project 0377_Iberphenol_6_E.

\section{Transparency document}

Transparency document related to this article can be found online at http://dx.doi.org/10.1016/j.fct.2018.06.006.

\section{References}

Akram, M., 2013. Minireview on Achillea millefolium Linn. J. Membr. Biol. 246, 661-663.

Anantharaju, P.G., Gowda, P.C., Vimalambike, M.G., Madhunapantula, S.V., 2016. An overview on the role of dietary phenolics for the treatment of cancers. Nutr. J. 15, 99

Ashkenazi, A., Salvesen, G., 2014. Regulated cell death: signaling and mechanisms. Annu. Rev. Cell Dev. Biol. 30, 337-356.

Bandyopadhyay, G., Biswas, T., Roy, K.C., Mandal, S., Mandal, C., Pal, B.C., Bhattacharya, S., Rakshit, S., Bhattacharya, D.K., Chaudhuri, U., Konar, A., Bandyopadhyay, S., 2004. Chlorogenic acid inhibits Bcr-Abl tyrosine kinase and triggers p38 mitogenactivated protein kinase-dependent apoptosis in chronic myelogenous leukemic cells. Blood 104, 2514-2522.

Baretta, I.P., Felizardo, R.A., Bimbato, V.F., dos Santos, M.G., Kassuya, C.A., Gasparotto Junior, A., da Silva, C.R., de Oliveira, S.M., Ferreira, J., Andreatini, R., 2012. Anxiolytic-like effects of acute and chronic treatment with Achillea millefolium L. extract. J. Ethnopharmacol. 140, 46-54.

Belkaid, A., Currie, J.C., Desgagnes, J., Annabi, B., 2006. The chemopreventive properties of chlorogenic acid reveal a potential new role for the microsomal glucose-6-phosphate translocase in brain tumor progression. Canc. Cell Int. 6, 7.

Benedek, B., Kopp, B., 2007. Achillea millefolium L. s.l. revisited: recent findings confirm the traditional use. Wien Med. Wochenschr. 157, 312-314.

Bessada, S.M.F., Barreira, J.C.M., Barros, L., Ferreira, I.C.F.R., Oliveira, M.B.P.P., 2016. Phenolic profile and antioxidant activity of Coleostephus myconis (L.) Rchb.f.: an underexploited and highly disseminated species. Ind. Crop. Prod. 89, 45-51.

Budhidarmo, R., Day, C.L., 2015. IAPs: modular regulators of cell signalling. Semin. Cell Dev. Biol. 39, 80-90.

Candan, F., Unlu, M., Tepe, B., Daferera, D., Polissiou, M., Sokmen, A., Akpulat, H.A., 2003. Antioxidant and antimicrobial activity of the essential oil and methanol extracts of Achillea millefolium subsp. millefolium Afan. (Asteraceae). J. Ethnopharmacol. 87, 215-220.

Costa, E.V., Sousa, E., Choosang, K., Singh, S., Rocha, J., Lima, R.T., Pakkong, P., Ahmed, S., Vasconcelos, M.H., Montanari, C.A., Pinto, M.M., 2014. Structure based design, synthesis, and evaluation of potential inhibitors of steroid sulfatase. Curr. Top. Med. Chem. 14, 1033-1044.

Csupor-Loffler, B., Hajdu, Z., Zupko, I., Rethy, B., Falkay, G., Forgo, P., Hohmann, J., 2009. Antiproliferative effect of flavonoids and sesquiterpenoids from Achillea millefolium s.1. on cultured human tumour cell lines. Phytother Res. 23, 672-676.

Dias, M.I., Barros, L., Duenas, M., Pereira, E., Carvalho, A.M., Alves, R.C., Oliveira, M.B., Santos-Buelga, C., Ferreira, I.C., 2013. Chemical composition of wild and commercial Achillea millefolium L. and bioactivity of the methanolic extract, infusion and decoction. Food Chem. 141, 4152-4160.

Duriez, P.J., Shah, G.M., 1997. Cleavage of poly(ADP-ribose) polymerase: a sensitive parameter to study cell death. Biochem. Cell. Biol. 75, 337-349.

El-Deiry, W.S., 2016. p21(WAF1) mediates cell-cycle inhibition, relevant to cancer suppression and therapy. Canc. Res. 76, 5189-5191.

Flygare, J.A., Beresini, M., Budha, N., Chan, H., Chan, I.T., Cheeti, S., Cohen, F., Deshayes, K., Doerner, K., Eckhardt, S.G., Elliott, L.O., Feng, B., Franklin, M.C. Reisner, S.F., Gazzard, L., Halladay, J., Hymowitz, S.G., La, H., LoRusso, P., Maurer, B., Murray, L., Plise, E., Quan, C., Stephan, J.P., Young, S.G., Tom, J., Tsui, V., Um, J., Varfolomeev, E., Vucic, D., Wagner, A.J., Wallweber, H.J., Wang, L., Ware, J., Wen, Z., Wong, H., Wong, J.M., Wong, M., Wong, S., Yu, R., Zobel, K., Fairbrother, W.J., 2012. Discovery of a potent small-molecule antagonist of inhibitor of apoptosis (IAP) proteins and clinical candidate for the treatment of cancer (GDC-0152). J. Med. Chem. 55, 4101-4113.

Gouthamchandra, K., Sudeep, H.V., Venkatesh, B.J., Shyam Prasad, K., 2017. Chlorogenic acid complex (CGA7), standardized extract from green coffee beans exerts anticancer effects against cultured human colon cancer HCT-116 cells. Food Sci. Hum. Wellness 6, 147-153.

Holohan, C., Van Schaeybroeck, S., Longley, D.B., Johnston, P.G., 2013. Cancer drug 
resistance: an evolving paradigm. Nat. Rev. Canc. 13, 714-726.

In, J.K., Kim, J.K., Oh, J.S., Seo, D.W., 2016. 5-Caffeoylquinic acid inhibits invasion of non-small cell lung cancer cells through the inactivation of p70S6K and Akt activity: involvement of p53 in differential regulation of signaling pathways. Int. J. Oncol. 48, 1907-1912.

Kintzios, S., Papageorgiou, K., Yiakoumettis, I., Baricevic, D., Kusar, A., 2010. Evaluation of the antioxidants activities of four Slovene medicinal plant species by traditional and novel biosensory assays. J. Pharm. Biomed. Anal. 53, 773-776.

Langemann, D., Trochimiuk, M., Appl, B., Hundsdoerfer, P., Reinshagen, K., Eschenburg, G., 2017. Sensitization of neuroblastoma for vincristine-induced apoptosis by Smac mimetic LCL161 is attended by G2 cell cycle arrest but is independent of NFkappaB, RIP1 and TNF-alpha. Oncotarget 8, 87763-87772.

Lee, F.A., Zee, B.C., Cheung, F.Y., Kwong, P., Chiang, C.L., Leung, K.C., Siu, S.W., Lee, C., Lai, M., Kwok, C., Chong, M., Jolivet, J., Tung, S., 2016. Randomized phase II study of the x-linked inhibitor of apoptosis (XIAP) antisense AEG35156 in combination with sorafenib in patients with advanced hepatocellular carcinoma (HCC). Am. J. Clin. Oncol. 39, 609-613.

Lin, C.H., Chang, C.Y., Lee, K.R., Lin, H.J., Chen, T.H., Wan, L., 2015. Flavones inhibit breast cancer proliferation through the Akt/FOXO3a signaling pathway. BMC Canc. 15, 958.

Lopes-Rodrigues, V., Di Luca, A., Sousa, D., Seca, H., Meleady, P., Henry, M., Lima, R.T., O'Connor, R., Vasconcelos, M.H., 2016. Multidrug resistant tumour cells shed more microvesicle-like EVs and less exosomes than their drug-sensitive counterpart cells. Biochim. Biophys. Acta 1860, 618-627.

Mahadevan, D., Chalasani, P., Rensvold, D., Kurtin, S., Pretzinger, C., Jolivet, J., Ramanathan, R.K., Von Hoff, D.D., Weiss, G.J., 2013. Phase I trial of AEG35156 an antisense oligonucleotide to XIAP plus gemcitabine in patients with metastatic pancreatic ductal adenocarcinoma. Am. J. Clin. Oncol. 36, 239-243.

Merkel, O., Taylor, N., Prutsch, N., Staber, P.B., Moriggl, R., Turner, S.D., Kenner, L., 2017. When the guardian sleeps: reactivation of the p53 pathway in cancer. Mutat. Res. 773, 1-13.

Miranzadeh, S., Adib-Hajbaghery, M., Soleymanpoor, L., Ehsani, M., 2015. Effect of adding the herb Achillea millefolium on mouthwash on chemotherapy induced oral mucositis in cancer patients: a double-blind randomized controlled trial. Eur. J. Oncol. Nurs. 19, 207-213.

Murad, L.D., Soares Nda, C., Brand, C., Monteiro, M.C., Teodoro, A.J., 2015. Effects of caffeic and 5-caffeoylquinic acids on cell viability and cellular uptake in human colon adenocarcinoma cells. Nutr. Canc, 67, 532-542.

Philchenkov, A., Miura, K., 2016. The IAP protein family, SMAC mimetics and cancer treatment. Crit. Rev. Oncog. 21, 185-202.

Pluta, P., Jeziorski, A., Cebula-Obrzut, A.P., Wierzbowska, A., Piekarski, J., Smolewski, P., 2015. Expression of IAP family proteins and its clinical importance in breast cancer patients. Neoplasma 62, 666-673.

Potrich, F.B., Allemand, A., da Silva, L.M., dos Santos, A.C., Baggio, C.H., Freitas, C.S. Mendes, D.A.G.B., Andre, E., de Paula Werner, M.F., Marques, M.C.A., 2010. Antiulcerogenic activity of hydroalcoholic extract of Achillea millefolium L.: involvement of the antioxidant system. J. Ethnopharmacol. 130, 85-92.

Santos, T.d., Tavares, C., Sousa, D., Vaz, J.A., Calhelha, R.C., Martins, A., Almeida, G.M., Ferreira, I.C.F.R., Vasconcelos, M.H., 2013. Suillus luteus methanolic extract inhibits cell growth and proliferation of a colon cancer cell line. Food Res. Int. 53, 476-481.

Schmidt, V., Nagar, R., Martinez, L.A., 2017. Control of nucleotide metabolism enables mutant p53's oncogenic gain-of-function activity. Int. J. Mol. Sci. 18

Tozyo, T., Yoshimura, Y., Sakurai, K., Uchida, N., Takeda, Y., Nakai, H., Ishii, H., 1994. Novel antitumor sesquiterpenoids in Achillea millefolium. Chem. Pharm. Bull. (Tokyo) 42, 1096-1100.

Tsai, C.M., Yen, G.C., Sun, F.M., Yang, S.F., Weng, C.J., 2013. Assessment of the antiinvasion potential and mechanism of select cinnamic acid derivatives on human lung adenocarcinoma cells. Mol. Pharm. 10, 1890-1900.

Uniyal, S.K., Singh, K.N., Jamwal, P., Lal, B., 2006. Traditional use of medicinal plants among the tribal communities of Chhota Bhangal, Western Himalaya. J. Ethnobiol. Ethnomed. 2, 14.

Vasconcelos, M.H., Beleza, S.S., Quirk, C., Maia, L.F., Sambade, C., Guimaraes, J.E., 2000. Limited synergistic effect of antisense oligonucleotides against bcr-abl and transferrin receptor mRNA in leukemic cells in culture. Canc. Lett. 152, 135-143.

Vaz, J.A., Almeida, G.M., Ferreira, I.C., Martins, A., Vasconcelos, M.H., 2012. Clitocybe alexandri extract induces cell cycle arrest and apoptosis in a lung cancer cell line: identification of phenolic acids with cytotoxic potential. Food Chem. 132, 482-486.

Vichai, V., Kirtikara, K., 2006. Sulforhodamine B colorimetric assay for cytotoxicity screening. Nat. Protoc. 1, 1112-1116.

Vitalini, S., Beretta, G., Iriti, M., Orsenigo, S., Basilico, N., Dall'Acqua, S., Iorizzi, M., Fico, G., 2011. Phenolic compounds from Achillea millefolium L. and their bioactivity. Acta Biochim. Pol. 58, 203-209.

Vogelstein, B., Lane, D., Levine, A.J., 2000. Surfing the p53 network. Nature 408, 307-310.

Xu, R., Kang, Q., Ren, J., Li, Z., Xu, X., 2013. Antitumor molecular mechanism of chlorogenic acid on inducting genes GSK-3 beta and APC and inhibiting gene beta -catenin. J. Anal. Methods Chem. 2013, 951319. 